\title{
sciendo
}

DOI 10.2478/sbe-2019-0001

SBE no. 14(1) 2019

\section{A CLOSE LOOK INTO SUPPLIER POLICY CHANGES IN RESPONSE TO THEIR BUYERS' FINANCIAL STRESS}

\author{
ABDIEV Jamol \\ Eastern Illinois University \\ AKALIN Gurkan \\ Eastern Illinois University
}

\begin{abstract}
:
Trade credit, the credit extended to buyers by suppliers who let them buy now and pay later, is an important financing method for many buyers. Any policy change by buyers in accounts payable, a measure for trade credit, results in appreciation or frustration on the supplier side. Even though, such effects have been well documented in the literature, an empirical study on the subject is surprisingly lacking. As an example, a certain buyer might change the payment policy by extending or shortening the periods of the payments. We investigate how and if the payment policy change of the buyer affects the supplier's operations, especially on the perspective of inventory of suppliers. This study further investigates how changes in a firm's accounts payable days and accounts receivable days affect its inventory turnover days.
\end{abstract}

Key words: Trade Credit, Inventory, Payment Policy Change

\section{Introduction and Literature Review}

\subsection{Trade Credit and Trade Credit Policies}

Trade Credit has been a predominant way of a short-term financing and a significant portion of working capital for firms in different areas. According to Rajan and Zingales (1995), trade credit accounted for $17.8 \%$ of total assets for all U.S. firms even in the early 1990s. In addition, authors provided evidence that for European firms the percentage of trade credit in total assets was even higher during the same period. Based on a research of the capital structure of 822 firms in UK in 1995, trade credit or its equivalent accounted for about $62 \%$ of total debt for the firms (Aviral \& Raveesh, 2015). Tirole (2006) has shown that about $80 \%$ of U.S. firms offer trade credit financing for their products. According to Haley and Higgins (1973), the primary goal of inventory management is to minimize the inventory costs of the firm by optimizing quantity ordered 
and financing. Teng (2009) indicates that there are two benefits of trade credit to the supplier. First, some retailers may perceive trade credit as a price deduction and become new customers for this supplier (Nilsen, 2002). Second, trade credit can help the supplier to reduce days sales outstanding, as in order to take advantage of trade credit more often, a customer is willing to pay more promptly ( $\mathrm{Ng}$ et al., 1999). Firms with more financial constraints or firms with less access to bank loans are likely to use trade credit (see, e.g., Danielson \& Scott, 2004; Petersen \& Rajan, 1997). In addition, in some countries, small businesses struggle to get loans from banks because of complex loan processing procedures and poor banking system. As a result, they are likely to choose trade credit. In Sri Lanka, 35 percent of small firms can access a loan or a line of credit, but around 14 percent of those who applied were not approved for loans (Gamage, 2015). However, Deloof \& Jegers (1996) conclude that suppliers using trade credit as a way of financing their customers' purchases limit the extension of accounts payable days when they face a shortage of liquid funds.

Previous literature offers several explanatory theories for the adoption of trade credit financing by companies. For example, the most popular explanations are information asymmetry between suppliers and their buyers, discrimination arguments, monitoring advantages, insurance, product quality, bankruptcy, opportunistic behavior, and externalities (Biais \& Gollier, 1997; Smith, 1987). Other research findings by Seifert et al. (2013) investigate all literature related to trade credit and find motives for utilizing trade credit by suppliers and buyers. From all previous literature, they find that major types of motives for suppliers to adopt trade credit are capital access, product market position, price elasticity, collateral value, credit information, and non-salvageable investment. Seifert et al. (2013) also show that three predominant motives for buyers to use trade credit are transaction pooling, credit rationing, and control protection. Moreover, based on Seifert et al. (2013), trade credit can play the role of coordination mechanism for buyers and their suppliers.

Furthermore, Wilson and Summers (2002) argue that suppliers whose buyers order more often are likely to offer trade credits with longer time periods to pay, showing that trade credit can reduce payment transaction costs. If a firm borrows money to pay for inventory, it has to pay interest rate as part of the carrying cost (Asadabadi, 2016). Also, Long et al. (1993) and Gill et al. (2010) provide empirical evidence that trade credit helps buyers to assess quality of the product they bought before making payments for the products. Ward and Chapman (1987) argue that suppliers of inventories can benefit from the fact that repayment of the trade credit is dependent on the use or sale of goods by buyers because the fact encourages buyers to order in large quantities, reducing the cost of credit.

Another set of research looked at the variations of trade credit use across firms, industries and time. $\mathrm{Ng}$ et al. (1999) claims that the variation of credit terms among different industries is high whereas it is low within each industry. The level of variation within each industry is also different from one industry to another, and this was shown by the degree of variation of actual payment delays within each industry (Cetorelli \& Strahan, 2006). Additionally, Wilson and Summers (2002) conducted interviews with about 30 managers and found that their companies, according to the managers, offer over 1000 
different credit terms internationally. The authors concluded that in some industries, credit terms can change from one customer to another. Meric et al. (2017) found that European firms have more efficient accounts receivable management and higher fixed turnover rates whereas Asian manufacturing firms' financials show higher inventory turnover and sales growth rates. For industrialized countries, except for Italy, the median accounts receivable ranges from $13 \%$ to $40 \%$ of sales, and the range has not changed significantly over time. Trade credit changes from one industry to another one. While in most sectors accounts receivable exceeds accounts payable, in the retail sector we do not observe the same inequality (Seifert et al., 2013).

\subsection{Trade Credit and Inventory Relationship}

There are several researches completed on the relationship between trade credit and inventory. For instance, Makori and Jagongo (2013) find that the inventory turnover is positively associated with profitability of a firm, while accounts payable days are negatively associated with a firm's profitability. They also show that accounts receivables days and cash conversion period have a positive relationship with firm profitability. Mian \& Smith (1992) explain that extending accounts payable days and accounts payable policy provides both sides with several benefits, such as cost advantages, market power, and taxes. We will connect some dots from Makori and Jagongo (2013), by investigating the relationships between accounts payable days and inventory turnover days, and accounts receivable days and inventory turnover days. According to Deloof (2003), accounts receivable days, inventory turnover days, and accounts payable days can be used as measures of trade credit and inventory policies. The three variables that are important for a company that pursues to improve its cash-to-cash position are reduction in inventory days, reduction of accounts receivables collection days, and extension of accounts payable days (Hutchison \& Sushko, 2013). Moreover, Hutchison and Sushko (2013) found that there was a negative relationship between the number of days accounts payable and firm profitability, a finding that is consistent with the view that poorly performing firms wait longer to pay their bills. Moss and Stine (1993) argue that one of the ways to reduce receivables conversion period is to raise credit standards.

Other recent studies in this area include Daripa and Nilsen (2005). Daripa and Nilsen (2005) have empirically examined the relationship between trade credit and inventory. They found that suppliers shift the burden of higher inventories to buyers by offering them trade credit. Bougheas et al. (2009) further explore this area and claim that the buyers who buy more inventory, reserving higher levels of inventory, are likely to offer trade credit to their own customers. The results of Bougheas et al. (2009) show that inventories have a significant and negative impact on accounts receivable while the relationship between inventory levels and accounts payable is not significant after controlling firm-specific characteristics. Moreover, the researchers provide evidence that the impact of inventories on trade credit is explained by the size of the firm, showing that there is a negative relationship between inventory holding costs and firm size. The research of Bougheas et al. (2009) is based on a sample of UK firms from FAME database and uses GMM estimates. Our work further investigates similar relationships between accounts payable days, accounts receivable days, and inventory turnover days, using 
publicly-traded U.S. companies. Following the previous literature, we predict the following hypotheses:

H1: An increase/decrease in a firm's accounts payable days positively/negatively affects its inventory turnover days.

H2: An increase/decrease in a firm's accounts receivable days negatively/positively affects its inventory turnover days.

H3: A positive/negative change of accounts payable days of a firm year-over-year positively/ negatively affects its inventory turnover days.

H4: A positive/negative change in accounts receivable days of a firm year-over-year negatively/positively affects its inventory turnover days.

Although many studies have been extensively conducted to show the relationship between the trade credit and the inventory to date, most of them are limited to empirically showing the relationship between the payments and inventory on both sides of supplier and buyer. The power in supply chain affects the inventory policy. When a supplier is more powerful than its buyer, the buyer holds relatively larger inventories (Emery \& Marquez, 2011). The deferred cash flow from buyer might affect the supplier's operations to be constrained, especially supplier under financial distress, while the buyer is able to achieve financial surplus over short term periods. The adverse signal of a buyer coming from the deferred payment indicates the reduction of demand for the continued production over short-term periods (Nilsen, 2002). Thus, a supplier would confront higher inventory levels deviated the targeted level, causing supplier to have higher costs.

The holding of inventory at targeted level is the trade-off between the increase of holding costs and the transfer of costs to customers. A supplier or buyer often uses trade credit to maintain such targeted level of inventory. The difference between accounts receivable and payable causes the control of the inventory to be complicated along with large level of inventories (Haley \& Higgins, 1973). Accounts payable of a buyer is tightly related with buyer's inventories policy. Also, accounts payable of a buyer is accounts receivable of a supplier. Thus, the payment policy change of a buyer would significantly affect the supplier' inventory performance under tight supply chain relationship. Our study focuses on buyer firms that have long-term relationships with their suppliers. Thus, the following hypothesis is suggested:

H5: Accounts payable days of buyer positively affects inventory turnover days on the side of its supplier.

\section{Methodology and Data}

\subsection{Data Characteristics}

Financial data for our study were from the Research Insight Database for all companies in the S\&P 500 index. To be included in S\&P 500 index, a company must 
satisfy several liquidity-based size requirements. The company must have at least $\$ 6.1$ billion market capitalization. Annual dollar value traded to float-adjusted market capitalization must be greater than 1.0 for the S\&P 500 companies. Furthermore, for a company to be included in the index, it is required to have a minimum monthly trading volume of 250,000 shares in each of the six months right before the evaluation date. Initially, we retrieved data for the companies in the S\&P 500 index for years from 1970 to 2016 , creating 21,536 firm-year observations. To find suspect companies with potential accounts payable policy changes, we found standard deviations of accounts payable days of companies. We excluded companies that had less than 5 years of data and did not have significant changes in their accounts payable days in the given years. To see the impact of accounts payable days of buyer on inventory of supplier, we excluded firms with accounts payable days that do not have significant standard deviations. After further analysis of standard deviations of accounts payable days of the list of companies, the number of our companies was reduced to 56 companies.

The supplier information for 54 of the 56 companies was from Capital IQ database. Two of them did not have any supplier information. After we collected supplier financial information from Research Insight Database, we had 191 publicly-traded US-based suppliers for 54 buyers, providing us with 4184 firm-year observations. Since all companies are publicly-traded companies with much capacity to obtain resources from capital markets and banks, we are not likely to observe many firms that are financially constrained.

Our research requires firm-year observations to have necessary data to calculate accounts payable days, inventory turnover days, and accounts receivable days. Inventory turnover days or days sales of inventory are calculated by dividing cost of sales (COGS) by inventory and multiplying the result by 365 days.

$$
\text { Invontory Tumover Days }=\frac{\text { COGS }}{\text { Invontory }} \times 866^{\circ}
$$

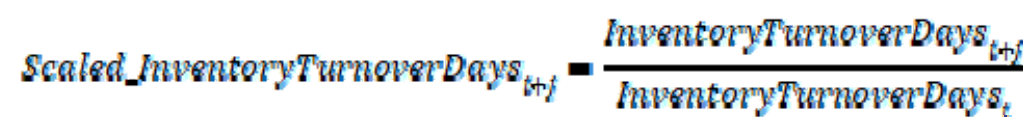

where

$$
\text { to the first year whth avallable data for } a \text { ftrm }
$$

and $t+f=$ the chrrent $y \& a x(f=1,2,8, \ldots n)$.

We estimated accounts payable days by dividing accounts payables by cost of sales and multiplying the result by 365 days. Finally, we found accounts receivable days by dividing accounts receivables by sales of each company and multiplying the result by 365 days.

$$
\text { Accounts Rocolvable Days }=\frac{\text { Accounts Payable }}{\text { CoGS }} \times 865
$$




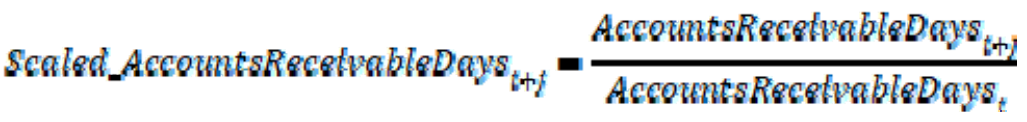

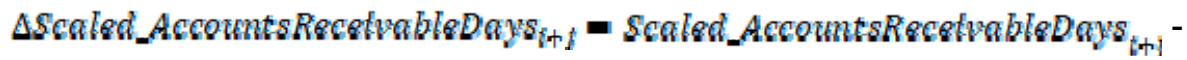

Scaled_AccountsRecolvableDays inti-1 $_{1}$

Accounts Payable Days $=\frac{\text { Accounts Recolvable }}{\text { Sales }} \times 865$

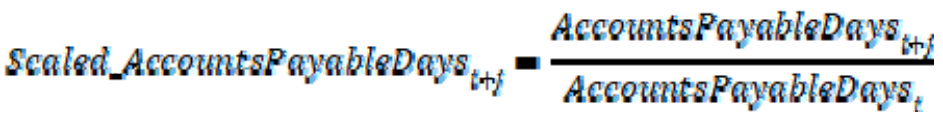

Ascaled_AccountsPayableDays $s_{i+1}=$ Scaled_AccomtsPayableDays ${ }_{t+1}-$

Scaled_AccountsPayableDays ${ }_{i+i-1}$

We scaled inventory turnover days by dividing each year's observation by the first given (available) year-observation for each firm. Graph 1 below shows a trade credit relationship between a buyer and its supplier.

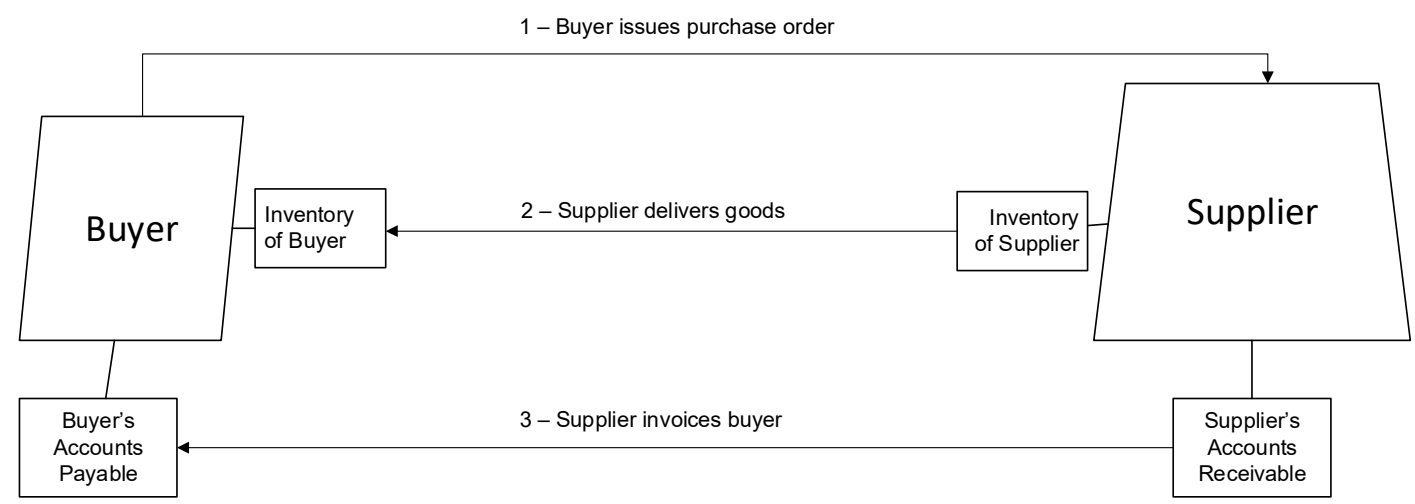

Figure 1: Trade Credit Relationship Between a Buyer and Its Supplier

\subsection{Regression Model}

We define the dependent variable $S C_{-} I N V T_{-} D a y S_{-} S$ to represent scaled inventory turnover days of a supplier. The independent variables in our model are

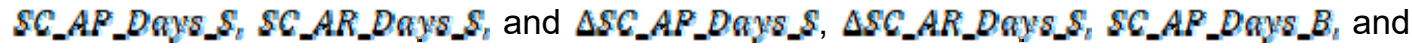
Lag1_SC_INVT_Days_S. SC_AP_DQYS_S stands for scaled accounts payable days of a supplier while $S C_{-} A R_{-} D Q Y s_{-} S$ denotes scaled accounts receivable days of a supplier. $S C_{-} A P_{-} D a y s_{-} B$ represents scaled accounts payable days of a buyer. $\triangle S C_{-} A P_{-} D q y S_{-} S$ and $\triangle S C_{-} A R_{-} D Q y S_{-} S$ are changes in scaled accounts payable days and in accounts receivable 
days of a supplier, respectively. The last independent variable in the model is Lag1_SC_INVT_Days_S that signifies a one-year lag of scaled inventory turnover days of a supplier company. Our main model is as follows:

\section{SC_INVT_Days_S}

$$
\begin{aligned}
& -\beta_{0}+\beta_{1} S C_{-} A P_{-} D a y S_{-} S+\beta_{2} S C_{-} A R_{-} D a y S_{-} S+\beta_{3} \Delta S C_{-} A R_{-} D a y S_{-} S \\
& \text { + } \beta_{4} \triangle S C_{-} A P_{-} \text {Days_S + } \beta_{8} S C_{-} \text {AP_Days_B }+\beta_{6} L a g 1_{-} S C_{-} I N V T_{-} D a y S_{-} S \\
& +8
\end{aligned}
$$

\section{Table 1: Descriptive Statistics}

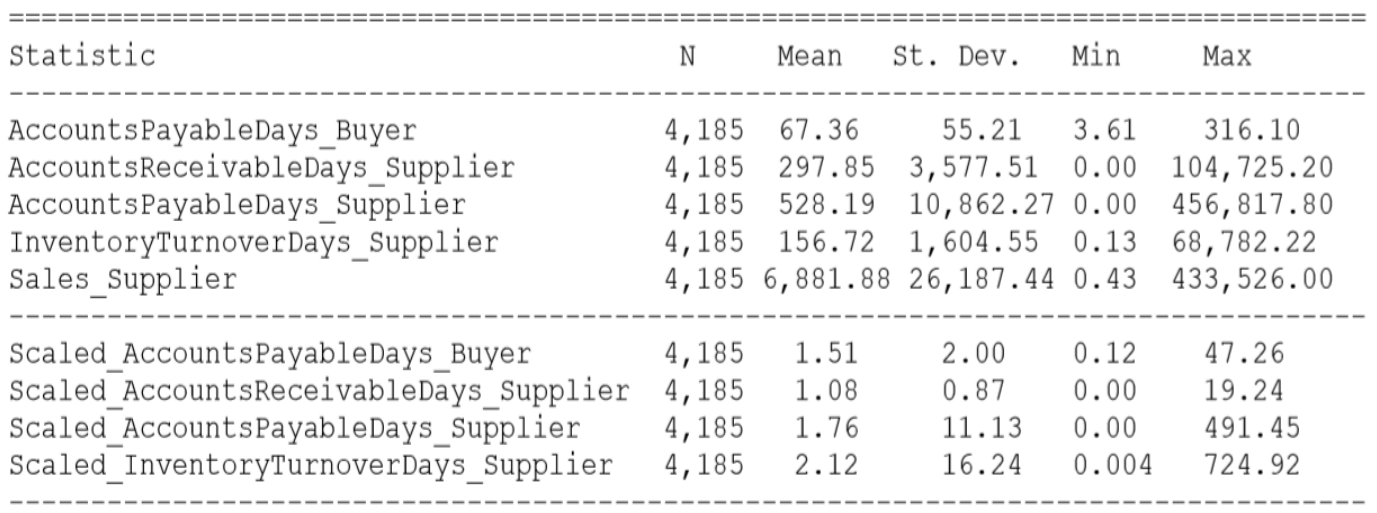

The Table 1 presents the descriptive statistics of the selected variables from data that were used to calculate the variable ratios used as independent and dependent variables in our regression model. The top line in the Table 1 is accounts payable days of a buyer. Accounts payable days for buyers has a mean (standard deviation) of 67 (55) days while accounts payable days for suppliers have a mean (standard deviation) of 528 $(10,862)$ days. Accounts receivable days for suppliers has a mean (standard deviation) of $298(3,577)$ days. Comparison of suppliers' and buyers' accounts payable days shows that suppliers have significantly higher accounts payable days. Overall, results are consistent with the notion that different industries have different amount of accounts payable and accounts receivable days. Inventory turnover days has a mean (standard deviation) of 156 (1604) days. The size (sales) of companies also differs a lot from one to another. While mean (standard deviation) of sales of the suppliers in our sample is $\$ 6,882(26,187)$ million, the maximum of sales is $\$ 433,526$ million. As a result, the corresponding scaled proxies for inventory turnover days, accounts payable days, and accounts receivable days have high standard deviations compared to the mean of the scaled variables.

\section{Results}

Graph 2 shows how firm's accounts payable days, accounts receivable days, change in scaled accounts payable days, change in scaled accounts receivable days, and buyer's accounts payable days affects the firm's inventory turnover days. 


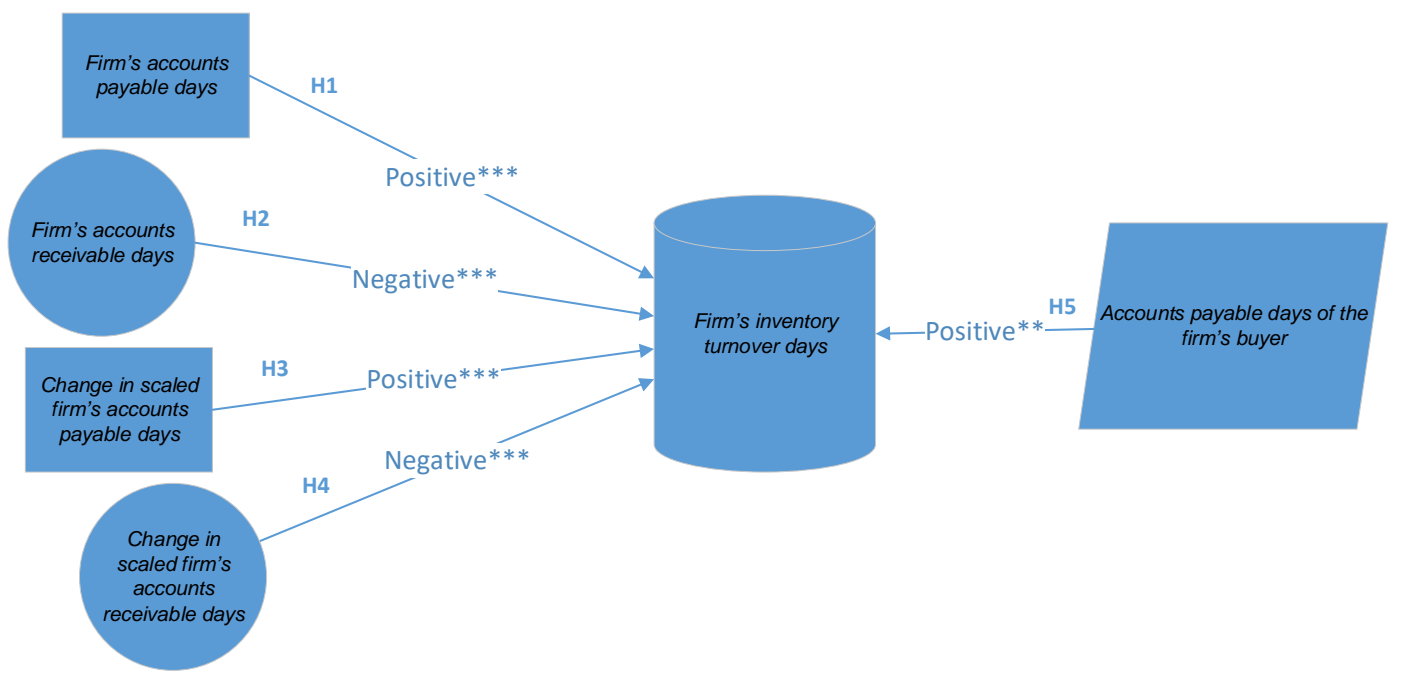

Figure 2. Results of the Study in a Visual Form (Note: ${ }^{*} p<0.1 ;{ }^{* *} p<0.05 ;{ }^{* * *} p<0.01$ )

In the Table 2, we present results of the regression model described earlier, which we use to evaluate the relationship between inventory turnover days of supplier and accounts payable days of supplier, accounts receivable days of supplier, change in accounts payable days of supplier, change in accounts receivable days of supplier, as well as accounts payable days of buyer. The $R$ square of the regression results is 0.976 . As we expected in

Hypothesis 1, an increase/decrease in a firm's accounts payable days positively/negatively affects its inventory turnover days, which is supported by coefficient = 0.24 and t-value $=18.23$ for $S C_{-} A P_{-} D a y s_{-} S_{\text {. }}$. This relationship between accounts payable days and inventory turnover days of supplier is positive and significant at $99 \%$ confidence level. The reason for the positive strong correlation between inventory turnover days and accounts payable days of a firm might be a purchase of inventory using trade credit in a great quantity during the current year.

Hypothesis 2 is supported by the regression results. For SC_AR_Days_ 8 the coefficient is -0.24 and $t$-value $=-6.37$. This indicates that a significant and negative relationship exists between accounts receivable days and inventory turnover days or that an increase/decrease in a firm's accounts receivable days negatively/positively affects its inventory turnover days. If accounts receivables of a firm increases, meaning it might be extending accounts payable days in order to reduce inventory and inventory holding costs. As a result, buyers of this firm are buying more to take advantage of the extended credit terms, reducing the inventory of their supplier while increasing the accounts receivable of the supplier.

The regression results also support Hypothesis 3. According to the Table 2, the coefficient $=1.24$ and $t=95.79$ for $\triangle$ SC_AP_Days_\$ supports our Hypothesis 3 that a positive/negative change in accounts payable days of a firm year-over-year positively/ negatively affects its inventory turnover days. We can see that if the change in accounts payable days is positive, that might be because the firm's supplier is increasing its 
accounts receivable days or accounts payable days of the firm. If accounts payable days are extended, buyers want to take advantage of extended credit policies offered by suppliers and buy more inventory, increasing inventory turnover days. On the other hand, if change in accounts payable days is negative, it is likely that inventory turnover days of the firm decreases because of short accounts payable days provided by this firm's suppliers. When they are offered short accounts payable days, firms cannot buy or hold much inventory because they have to pay more often.

This study results supports Hypothesis 4 as well, which predicted that a positive/negative change in accounts receivable days of a firm year-over-year negatively/positively affects its inventory turnover days. The regression results for ASC_AR_Days_S show that coefficient $=-1.65$ and $t=-20.84$, suggesting a strong and negative relationship between $\triangle$ SC_AR_Days_S and that SC_INVT_Days_S. This might be because of more sales of inventory in trade credit this year compared to the last year. If there are more sales in trade credit, accounts receivable days increases and inventory turnover days decreases.

Our main hypothesis was also supported by the results, as the Table 2 shows that $S C_{-} A P_{-} D a y s_{-} B$ has a coefficient of 0.05 and t-value of 2.52 . Hypothesis 5 predicted that accounts payable days of buyer positively affects inventory turnover days on the side of its supplier.

Table 2: Regression Results

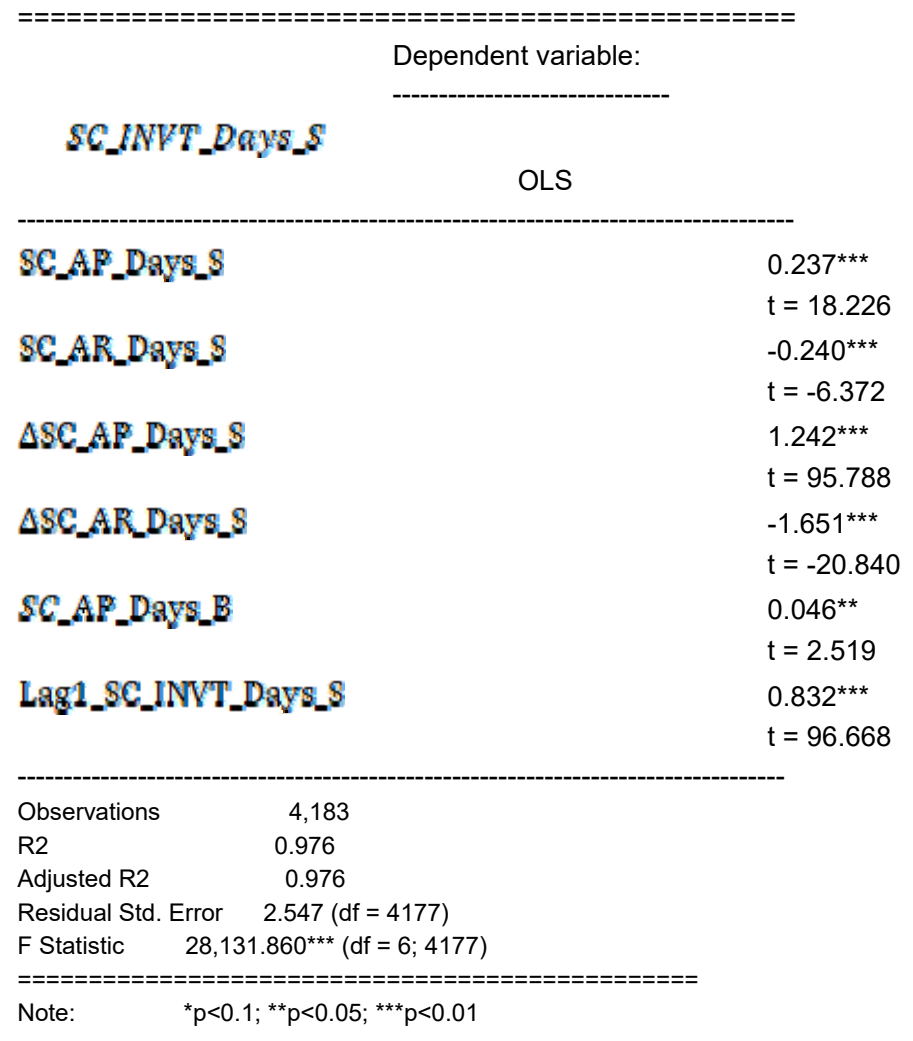


The relationship is significant at $95 \%$ level of confidence. Although companies have try to keep their inventories lean, they cannot do so when their buyers are experiencing financial stress or they have an increase in accounts payable amount (Isaksson \& Seifert, 2014). If accounts payable increases, this might cause accounts payable days to increase as well. Increasing accounts payable days of buyer firms indicates that those firms are struggling to pay its short-term debt. In that situation, they are unable to buy more inventory. When suppliers have long-term relationship with their buyers, they cannot easily switch to other buyers, holding its inventory until its buyer's next purchase. As a result, increased accounts payable days by buyers positively affects inventory turnover days of suppliers.

\section{Conclusion}

When buyers are experiencing financial stress, they tend to extend their accounts payable days. As this study results show, this change in trade credit policy of buyers has a positive impact on the inventory turnover days of the firms' suppliers. Other relationships between accounts payable days, accounts receivable days, and inventory turnover days were investigated, indicating significance of relationships among them. Our study results can be useful for companies to predict the implications of their inventory and trade credit policies. Knowing that unexpected trade credit policy changes on buyer's side have a significant impact on the supplier firm's inventory helps managers avoid related risks and make better decisions.

The buyer and supplier firms in our sample are limited to publicly-traded U.S. based companies. 54 suppliers in the data are S\&P 500 companies, indicating that our sample size for suppliers consists of large companies. They are required to have at least $\$ 6.1$ billion market capitalization to join S\&P 500. Our study can be extended to smaller firms that are not publicly traded. As more small and private firms are added to the sample of this study, it is expected that the relationships become more significant because smaller firms, compared with larger firms, are more dependent on trade credit and on fewer number of suppliers. It will be easier to see the impact of accounts payable policy changes of buyers on inventory turnover days of suppliers.

\section{References}

Asadabadi, M. R. (2016). A revision on cost elements of the EOQ model. Studies in Business and Economics, 11(1), 5-14.

Aviral, K. T., \& Raveesh, K. (2015). Determinants of capital structure: a quantile regression analysis. Studies in Business and Economics, 10(1), 16-34.

Biais, B., \& Gollier, C. (1997). Trade credit and credit rationing. The Review of Financial Studies, 10(4), 903-937.

Bougheas, S., Mateut, S., \& Mizen, P. (2009). Corporate trade credit and inventories: New evidence of a trade-off from accounts payable and receivable. Journal of Banking \& Finance, 33(2), 300-307.

Cetorelli, N., \& Strahan, P. E. (2006). Finance as a barrier to entry: Bank competition and industry structure in local US markets. The Journal of Finance, 61(1), 437-461. 
Danielson, M. G., \& Scott, J. A. (2004). Bank loan availability and trade credit demand. Financial Review, 39(4), 579-600.

Daripa, A., \& Nilsen, J. (2005). Subsidizing inventory: a theory of trade credit and pre-payment. Birkbeck, Department of Economics, Mathematics \& Statistics, Birkbeck Working Papers in Economics and Finance.

Deloof, M. (2003). Does working capital management affect profitability of Belgian firms? Journal of business finance \& accounting, 30(3-4), 573-58.

Deloof, M., \& Jegers, M. (1996). Trade credit, product quality, and intragroup trade: some European evidence. Financial management, 25(3), 33-43.

Emery, G. W., \& Marques, M. A. (2011). The effect of transaction costs, payment terms and power on the level of raw materials inventories. Journal of Operations Management, 29(3), 236249.

Gamage, P. (2015). Bank finance for small and medium-sized enterprises in Sri Lanka: issues and policy reforms. Studies in Business and Economics, 10(2), 32-43.

Gill, A., Biger, N., \& Mathur, N. (2010). The relationship between working capital management and profitability: Evidence from the United States. Business and Economics Journal, 10(1), 1-9.

Haley, C. W., \& Higgins, R. C. (1973). Inventory policy and trade credit financing. Management science, 20(4-part-i), 464-471.

Hutchison, M., \& Sushko, V. (2013). Impact of macro-economic surprises on carry trade activity. Journal of Banking \& Finance, 37(4), 1133-1147.

Isaksson, O. H., \& Seifert, R. W. (2014). Inventory leanness and the financial performance of firms. Production Planning \& Control, 25(12), 999-1014.

Long, M. S., Malitz, I. B., \& Ravid, S. A. (1993). Trade credit, quality guarantees, and product marketability. Financial management, 22(4), 117-127.

Makori, D. M., \& Jagongo, A. O. (2013). Working Capital Management and Firm Profitability: Empirical Evidence from Manufacturing and Construction Firms Listed on Nairobi Securities Exchange, Kenya.

Meric, G., Welsh, C., Scarpa, R., \& Meric, I. (2017). A comparison of the financial characteristics of European and Asian manufacturing firms. Studies in Business and Economics, 12(3), 112125.

Mian, S. L., \& Smith, C. W. (1992). Accounts receivable management policy: theory and evidence. The Journal of Finance, 47(1), 169-200.

Moss, J. D., \& Stine, B. (1993). Cash conversion cycle and firm size: a study of retail firms. Managerial Finance, 19(8), 25-34.

$\mathrm{Ng}$, C. K., Smith, J. K., \& Smith, R. L. (1999). Evidence on the determinants of credit terms used in interfirm trade. The journal of finance, 54(3), 1109-1129.

Nilsen, J. H. (2002). Trade credit and the bank lending channel. Journal of Money, Credit, and Banking, 34(1), 226-253.

Petersen, M. A., \& Rajan, R. G. (1997). Trade credit: theories and evidence. The review of financial studies, 10(3), 661-691.

Rajan, R. G., \& Zingales, L. (1995). What do we know about capital structure? Some evidence from international data. The journal of Finance, 50(5), 1421-1460.

Seifert, D., Seifert, R. W., \& Protopappa-Sieke, M. (2013). A review of trade credit literature: Opportunities for research in operations. European Journal of Operational Research, 231(2), 245-256.

Smith, J. K. (1987). Trade credit and informational asymmetry. The journal of finance, 42(4), 863872.

Teng, J. T. (2009). Optimal ordering policies for a retailer who offers distinct trade credits to its good and bad credit customers. International Journal of Production Economics, 119(2), 415-423. 
Tirole, J. (2006): The theory of corporate finance. Princeton University Press.

Ward, S. C., \& Chapman, C. B. (1987). Inventory control and trade credit - A reply to Daellenbach. Journal of the Operational Research Society, 38(11), 1081-1084.

Wilson, N., \& Summers, B. (2002). Trade credit terms offered by small firms: Survey evidence and empirical analysis. Journal of Business Finance \& Accounting, 29(3-4), 317-351. 